\title{
Understanding the drivers of consumer-brand identification
}

\section{Sihvonen, Jenniina}

2019-09

Sihvonen , J 2019 , ' Understanding the drivers of consumer-brand identification ' , Journal of Brand Management, vol. 26 , no. 5 , pp. 583-594 . https://doi.org/10.1057/s41262-018-00149-z

http://hdl.handle.net/10138/308175

https://doi.org/10.1057/s41262-018-00149-z

Downloaded from Helda, University of Helsinki institutional repository.

This is an electronic reprint of the original article.

This reprint may differ from the original in pagination and typographic detail.

Please cite the original version. 
CONCEPTUAL PAPER

\title{
Understanding the drivers of consumer-brand identification
}

\begin{abstract}
The purpose of this study is to develop a holistic understanding of the drivers of consumer-brand identification (CBI) from a consumer's perspective; in other words, to explicate why and how consumers form identity-based connections with brands. In this conceptual study the drivers of CBI are discussed by weaving together different perspectives presented in the extensive literature on identity-based consumer behaviour. The study at hand conceptualizes the drivers of CBI by acknowledging consumer's personality, life tasks and life values together with brand personality, brand promise and brand community as the main factors underlying the realization of a selfbrand connection. The paper presents different scenarios for consumer-brand identification and related managerial implications. The study distinguishes three drivers of CBI: 1) the personality driver, 2) the lifestyle driver, and 3) the values driver. A call is made for empirical studies that would examine the significance of each driver of CBI in differing contexts and product categories. The challenges to and possibilities for brand identity management are addressed. The study challenges the different schools of thought prevalent in contemporary brand management literature in approaching the drivers of CBI more holistically.
\end{abstract}

Keywords: consumer-brand identification, brand relationship, lifestyle, values, brand personality 


\section{Understanding the drivers of consumer-brand identification}

Brand is not only the label of a product, a specific offer, or a distinction perceived by a customer (Lencastre \& Corte-Real, 2010), but is something that a consumer builds a relationship with (Fournier, 1998). In essence, the goal of brand identity management is to develop brands that customers can strongly identify with. This notion has given rise to brand studies focusing on the compatibility/incompatibility of brand characteristics with those of consumers (e.g. Ahuvia, 2005; Lam et al., 2012; Lam et al., 2013; Mathews, 2015). On the one hand, understanding of consumers' identification with a brand explicates why, when and how brands help consumers to articulate their identities (Stokburger-Sauer et al., 2012: 406); on the other hand, it avoids falling for branding myopia that sees brands as ends in themselves and overlooks the critical role of brands as means to an end on the consumer's side.

In spite of the vast discussion around the topics of consumer and brand identities, surprisingly few studies (Stokburger-Sauer et al., 2012; Lam et al., 2012) have shed light on the drivers of consumer-brand identification (CBI), leaving a gap for research that would take a holistic and non-context-dependent perspective on the matter. The purpose of this study is to develop a holistic understanding of the drivers of CBI; in other words, to explicate why and how consumers form identity-based connections with brands. In this study CBI is discussed by weaving together different perspectives presented in the literature on consumer identity work and brand symbolism.

The study at hand conceptualizes the drivers of CBI by acknowledging consumer's personality, life tasks and values together with brand personality, promise and community as the main factors underlying the realization of a self-brand connection. The conceptual contribution evolves from relating these different research avenues on consumer identities towards an 
integrated whole (MacInnis, 2011). This study contributes to the literature on brand identity management by showing that consumers' identifications with brands have different drivers and outcomes.

The remainder of the article begins by connecting identity construction and consumption, and continues by determining the groundings for CBI from a consumer perspective. Then, the drivers of CBI are outlined and discussed in the light of existing branding paradigms, after which different possible CBI types and their specific calls for brand management are outlined. The paper concludes with the managerial implications, conclusions, limitations, and suggestions for further studies.

\section{Connections of identity and consumption}

Consumer identity has undeniably been a widely discussed topic in the field of marketing. On the one hand, there is a strong psychological school of thought focusing on the consumers' individual meaning making and relationships with brands; on the other hand, there is a sociologically oriented stream of research that highlights the importance of culturally situated social groupings and social identification. Indeed, consumers can identify with brands at multiple levels, such as a car owner, owner of an Audi, or owner of a sports coupe, or at all of these levels (Kuenzel \& Halliday, 2008: 294).

A review of prior studies on consumer identity work reveals that the identity issues related to CBI have been studied by different research traditions (see Kirmani, 2009). First, the psychology-oriented stream of research in front has applied concepts such as attachment (Wallendorf and Arnould, 1988; Schultz et al., 1989; Ball and Tasaki, 1992; Kleine et al., 1995; 
Sivadas and Venkatesh, 1995; Thomson et al., 2005; Swaminathan et al., 2009), brand love (Ahuvia, 2005; Carroll and Ahuvia, 2006; Albert et al., 2013; Batra et al., 2012), and brand engagement in self-concept (Sprott et al., 2009). Second, a more social psychologic stream has addressed identity formation in terms of the social context of a consumer (Deaux, 1992) including social roles and life tasks of consumers in their everyday lives with conceptualizations such as brand-relationship quality (Fournier, 1998; Smit et al., 2007), and brand/customer/consumer engagement (Bowden, 2009; Hollebeek, 2011; Gambetti et al., 2012). Third, research on brand communities (e.g. Muniz and O'Guinn, 2001; McAlexander et al., 2002; Schau et al., 2009) has been mainly grounded in sociology and cultural studies. This stream of research has focused on exploring brand's role in enabling consumers to form social identities by carrying out rituals and traditions, and developing a shared consciousness and moral responsibility (Muniz and O’Guinn, 2001).

A large body of literature points to the multifaceted nature and origins of identity. Identity is a complex entity, as it is a collection of multiple social and personal identities (Deaux, 1992). According to Reed et al. (2012: 312), there is no need to separate social and self-identity because both refer to the same concept, but are applied to a different domain. However, the different aspects of identity formation should be acknowledged. Identity relates to lifestyle and taste, as these are concrete manifestations of how identity is expressed and defined, and it develops dynamically during one's lifetime, involving both memories from the past and goals for the future (see Reed, 2002). McAdams (1996) has insightfully proposed a framework for studying human individuality by delineating three domains through which persons may be described: dispositional traits, personal concerns, and life stories. Prior studies on consumer identity have indeed tapped into these domains, but typically only one-sidedly, focusing either on consumers' 
personality traits, lifestyles or narrative identities. Therefore, there is a call for a study that would relate the different viewpoints to provide a better understanding of consumers' identity work, especially when it comes to making self-brand connections.

Without being context-specific, the study at hand aims to find solid conceptual reasoning behind the drivers of CBI. As Oyserman (2009), Kirmani (2009) and Halkoaho (2012) point out, identity-based choice in not a simple match up, but involves various types, goals and considerations. First, when outlining the drivers of CBI, we may think back to the states inherent to living: having, doing, and being (Sartre, 1966; Fromm, 1976; Shankar and Fitchett, 2002). These modes of existence are relevant to the question of who we are, and also form a bridge between acts and objects of consumption and identity. Accordingly, Fromm (1976: 20-21) points out that the fundamental modes of existence are not the separate qualities of an individual, but "different kinds of orientations toward self and the world". Together, these can be employed to understand the forming of identity connection when providing a linkage between motivation, cognition and behaviour. On this basis, also different roles of consumption objects in consumers' lives can be taken into account.

According to the classical conception, consumer goods may fulfill the functional, experiential and symbolic needs of a consumer (Park et al., 1986; Fournier, 1991; Nandan, 2005; Berthon et al., 2007). Functional needs encompass the utilitarian use of products in one's life by asking what does the product do, whereas experiential needs highlight subjective experiences and the hedonistic view of consumption motives, and symbolic needs encompass the identity role of a product in a consumer's life and social context (Fournier, 1991). Relatedly, Oyserman (2009: 250) defines that the consumer's 'identity-based motivation is the readiness to engage in identity-congruent action (...) and to use identity-congruent mindsets in making sense of the 
world." However, this does not mean that there would be only one type of action or one type of sense making as a result of identity-based motivation, since every consumer may have multiple identities, which occur more or less saliently at different points of time.

\section{Conceptual groundings for consumer-brand identification}

Studies on consumers' identity work have increased in number and also fragmented over the years. Various cognitive, emotional, and behavioural processes by which consumers incorporate objects of consumption have been recognized, yet often lacking conceptual comparison and/or integration (Schmitt, 2012). Therefore, the study at hand sets out to show how these entities are different and how they constitute a unified whole.

The literature on consumer-brand relationships, with Fournier (1998) at the forefront, has underlined that consumers have varied types of relationships with brands (Gómez-Suárez et al., 2017). Especially the concept of self-connection, also termed self-concept connection (e.g. Swaminathan et al., 2007) is a dimension of the consumer-brand relationship, which indicates the amount that the brand contributes to one's identity, values and goals (Fournier, 1998). Selfconnection has been considered as an equivalent concept to that of CBI, receiving also some empirical support (Papista and Dimitriadis, 2012).

Recently the construct of CBI has been derived from the discussion on consumer/customer-firm identification (Mael and Ashforth, 1992; Bhattacharya and Sen, 2003; Donavan et al., 2006; Kuenzel and Halliday, 2008; Stokburger-Sauer et al., 2012; Lam et al., 2013). CBI has been defined as the "consumer's psychological state of perceiving, feeling, and valuing his or her belongingness with a brand" (Lam et al., 2012: 308) and as a consumer's 
"state of oneness with a brand" (Stokburger-Sauer et al., 2012: 407). Therefore, the concept of self-brand congruity can be seen as a direct antecedent of CBI when addressing the similarity or dissimilarity between the self and the brand. Sirgy (1982) defines that the question of congruity denotes both brand congruity with self-image and with ideal self-image as the underlying consumer's motives, which include the need for self-consistency and self-esteem. In addition, Nandan (2005) reminds us that it is the customer who subjectively ascribes a persona to the brand based on his/her own associations and experiences, so the perceived (in)congruence occurs with brand image rather than with brand identity.

The CBI can be distinguished from consumer brand engagement, which describes "the level of an individual customer's motivational, brand-related and context-dependent state of mind characterised by specific levels of cognitive, emotional and behavioural activity in direct brand interactions" (Hollebeek, 2011: 790), Consumer brand engagement does not presume selfconnection with a brand, which is in the core of the concept CBI. Moreover, CBI differs from the concepts of brand personality and brand identity, as these do not represent the consumer's viewpoint in terms of identification with a brand (cf. DeChernatory, 1999; Aaker, 1997).

In their study, Kuenzel and Halliday (2008) discovered that prestige, satisfaction and corporate communication are antecedents of brand identification, whereas word-of-mouth and repurchase are consequences of brand identification when it comes to car owning. However, brand-dependent differences were found in the study. Prestige was a significant antecedent of identifying with a Mercedes-Benz, but not with a Ford brand (ibid, 2008: 299). This implies that consumer-brand identification is not always about full identification, but it can be partial and focused on a specific aspect of a brand-relationship. Moreover, the study of Millán and Díaz 
(2014) showed that consumers' brand identification positively influences loyalty and word-ofmouth communications.

The study of Tuškej et al. (2013), found that value congruity between the consumer and the brand influences CBI. Furthermore, brand commitment can be seen as a close concept to that of brand identification (ibid. 2013). However, it connotes a positive attitude toward the brand while the consumer and the brand remain separate entities (Ashforth et al., 2008). In addition, a high level of involvement can be seen as an important antecedent of CBI, as without involvement, the relationship lacks interest and relevance that would ground the relationship (see O'Cass, 2000; 2004). Typically, product involvement has been approached as interest towards a product category, but there are also studies that view involvement more as product-specific and including many dimensions such as a sign value of expressing the person's self (e.g. Quester \& Lim, 2003).

Only a few studies have shed light on the drivers of CBI, even though self-connections with brands have attracted a lot of interest among researchers since the 1990's. Stokburger-Sauer et al. (2012) outline brand distinctiveness, brand prestige, brand social benefits, brand warmth, and memorable brand experiences as the antecedents of CBI, thereby successfully bringing together the social, cognitive and affective factors, yet ignoring the functional value of brands in identity projects. Lam et al. (2012) recognized that consumer-brand relationships can be driven by both utilitarian and symbolic factors. Recently, Lam et al. (2013) distinguished instrumental (perceived quality), symbolic (self-brand congruence), and trait-based (consumer innate innovativeness) drivers of CBI in the context of the launch of a new brand. Without being context-specific, the study at hand aims to find solid conceptual reasoning behind the drivers of CBI. 


\section{CBI from the consumer perspective}

In the light of identity formation, the objects of consumption that consumers have and seek to acquire should be valued "by the extent to which they allow, enable, or facilitate a positive sense of being and identification", as Shankar and Fitchett (2002: 512) suggest. Similarly, Fournier (1998) defines that a consumer-brand relationship encompassing strong self-connection means that a brand is able to deliver on important identity concerns. Ogilvie and Rose (1995) point out that the categories of identity tasks include acquiring a positive state, maintaining a positive state, making a negative state positive, and avoiding a negative state. In a similar vein, Ahuvia (2005) suggests that consumers need to employ demarcating, compromising and synthesizing solutions to solve their identity conflicts throughout their lives. The principles of identity verification and identity conflict are of concern if the brand fails to deliver congruent or consistent representation of the brand identity to its customers (Reed et al., 2012), whereas loved brands and possessions can help consumers in their strivings towards a coherent self (Ahuvia, 2005).

Based on the discussion above, three basic concerns guiding identity formation can be distinguished: 1) the need for distinctiveness and self-enhancement, 2) the principle of identity relevance, and 3) the need for self-continuity.

In terms of the need for distinctiveness and self-enhancement, people seek ways to, on the one hand, affiliate themselves with others, and on the other hand, to distinguish themselves from others in social contexts. Consequently, consumers will find brands that have distinctive characteristics (values, personality traits, design, etc.) to be an attractive target for identification. Bandura (2001) points out that individuals strive for psychological matching processes through 
which they gain valuable outcomes such as interpersonal connections and enhanced self-esteem. A consumer is likely to incorporate the kinds of goods into the self-concept that are positively evaluated by relevant others, i.e. have favourable characteristics (Donavan et al., 2006). In this context, consumers tend to prefer brands that are similar to their ideal self-concept as a means of self-enhancement (Sirgy, 1982). On the other hand, the study by Malär et al. (2011) shows that emotional attachment to a brand is stronger when linked to a consumer's actual than ideal self.

The principle of identity relevance points out that a consumer is likely to favor brands that are somehow relevant to his/her own life (Reed et al., 2012). This notion is in line with the condition of high-involvement with a product category (e.g. high usage, expertise and interest). The studies by O'Cass $(2000 ; 2004)$ exemplify how high involvement with fashion clothing is linked to the consumer-object relationship and implies greater relevance to the self. The principle addresses the kind of consumption which becomes relevant for a consumer in terms of his/her specific life tasks and roles in life (Huffman et al, 2000). Miles (2000) points out that identities should not be discussed without reference to how they are constructed. In this regard, the concept of lifestyle becomes important as "it represents the way in which identities are mediated, produced and lived" (Bell and Hollows, 2005: 2). According to Giddens (1991), lifestyles are adopted by consumers rather than handed down to them. Thus, lifestyle is no longer associated with traditional groupings such as class and gender, but rather "connotes individuality, selfexpression and a stylistic self-consciousness" (Bell and Hollows, 2005: 4).

Finally, regarding the principle of self-continuity, people are motivated to maintain a consistent sense of self (Escalas, 2004; Oyserman, 2009) and therefore favor brands that actualize their self-definition and self-expression in a consistent way. It has become common to view identity development as cumulatively structured in terms of a narrative (McAdams, 1996; 
Escalas and Bettman, 2000; Ahuvia, 2005). According to narrative identity theories, identity construction has a temporal dimension. Narratives configure lived experiences of past, present, and anticipated future into a coherent whole and provide a sense of self-continuity in different life stages. Here, possessions may play a role in maintaining and preserving identity over time (Gentry et al., 1995).

In line with the discussion above regarding different needs, motives and goals of consumers, Schmitt (2012) has distinguished three levels of consumer engagement -selfcentered, object-centered, and social. Self-centered engagement in brand relationship emphasizes the personality connection and affective nature of the relationship. Object-centered engagement is functionally-driven by its nature with a purpose of gaining utilitarian benefits from the relationship, whereas social engagement highlights that a brand relationship has an interpersonal and social-cultural dimension. While Schmitt (2012) sees that these are unequally meaningful layers of psychological engagement with brands, this study suggests that they are equally important manifestations of distinctive drivers of $\mathrm{CBI}$ as they are linked to different identity needs of a consumer. Self-centered engagement can be understood in the light of the need for distinctiveness and self-enhancement, whereas object-centered engagement resonates with the need for identity relevance of the brand, and social engagement with the principle of selfcontinuity when providing a sense of community for the consumer.

\section{Outlining the drivers of $\mathrm{CBI}$}

Based on the discussion regarding the basic modes of human existence; having, doing, and being (e.g. Sartre, 1966), the different roles of consumption objects in consumers' lives, the key 
processes underlying identity-based consumer behaviour, and the different modes of consumer engagement with brands, we may now outline the key drivers of CBI. These three drivers of CBI from a consumer's perspective are personality driver, lifestyle driver, and values driver. This broader view encompasses consumers as dispositional, goal-striving and narrative entities, and addresses that self-connections between consumers and brands are grounded in important life themes and identity concerns (Baumgartner, 2002).

Figure 1 distinguishes the three drivers of $\mathrm{CBI}$ in layers according to the discussions above. First, the basic modes of human existence ground the drivers of CBI. Furthermore, we can embrace the three roles of brands in the lives of consumers, and identify that drivers put different emphasis on these roles.

Insert Figure 1 here. The three drivers of consumer-brand identification

The personality driver: The aspect of personality attaches to the self-expressive havingdimension in a consumer's life. Personality driver highlights the symbolic role of a brand in a consumer's life. Consumers vary in their preferences and tastes for different alternatives of consumer goods. The notion that consumers often associate themselves with their favorite brands gives support to the idea that an identity-bond develops with those objects of consumption towards which a person has a positive attitude. We may acknowledge taste-based groupings of consumers that respond to and even stem directly from brand-specific meanings (e.g. prestige). Accordingly, the personality driver implies that consumption objects may become resources when pointing to social relations, and status for consumers using shared symbolic signs in their social encounters. Thus, the personality driver attaches to the consumer's need for distinctiveness 
and self-enhancement. In this light, consumption facilitates the situating of oneself in a diversity of social contexts and the self in socialization (Wattanasuwan, 2005). Here, image congruence refers to the fit between the consumer's self-concept and the user image of a given brand (Kressmann et al., 2006). Moreover, this involves categorization processes, whereby the consumer sees him-/herself as a member of a brand community and emphasizes the perceived similarities with other members and dissimilarities with nonmembers (Algesheimer et al., 2005).

The lifestyle driver: The consumer's everyday tasks and goals refer to the doingdimension, which highlights the aspect of identity relevance that brands should address in consumers' lives. Thus, the lifestyle driver taps into the functional role. Consumption objects may respond to a person's current concerns and consumption intentions in many ways. Consumption objects become resources and instruments for a consumer when constructing his/her own lifestyle and managing the encountered life tasks. In this way we may recognize the lifestyle driver of CBI. This driver goes in line with the principle of identity relevance, which emphasizes consumption as decision making guided by the consumer's specific interests and life situations. Accordingly, the brand can become a central part of a consumer's life when linked to an engaging and meaningful activity (O'Cass, 2000). Also Giddens' (1991: 81) definition of lifestyle helps to explain the nature of the lifestyle driver: "A lifestyle can be defined as a more or less integrated set of practices which an individual embraces, not only because such practices fulfill utilitarian needs, but because they give material form to a particular form of self-identity." In other words, lifestyle is concrete and functional, rather than an abstract and symbolic aspect of a consumer's identity work. To exemplify, Maehle et al. (2011) found that consumers mention specific brands of technical appliances and cars as competent/incompetent in terms of how they succeed in meeting their quality and performance expectations. 
The consumer values driver: The being-dimension in human existence is reflected by the consumer's striving for coherent identity formation in line with own life values. The values driver relates to the experiential role of brand in a consumer's life and corresponds with the principle of self-continuity, as it is concerned with the consumer's individual striving for being true to oneself. Consumption can contribute to basic questions in life, such as what the priorities and necessities in life are, what to believe in, how to manage in life, and what to respect. Consumption then becomes a realization of different life themes and appreciations specific to an individual. When consumption is oriented towards the being-dimension, consumption objects are harnessed to reflect own values, thereby supporting identity development and emphasizing the values driver of CBI.

\section{The drivers of CBI in in connection with the paradigms within brand management}

By definition, brand management can be considered as "a communication function that consists of examining and planning how a brand should be positioned in the world, to what type of audience the brand should be targeted, and how the ideal reputation of the brand should be preserved" (Matusitz, 2014: 240). In consequence, brand managers become challenged by how to create and manage distinctive brand identity components and by the need to understand the psychological processes of the customers, such as individual and social meaning making (Zaichkowsky, 2010).

The shift from a product-driven to a consumer-driven brand management has been a topic for continuous discussion, since brand identity management and consumer-relationship management should be responsive to the changes that happen in the market place. Holt (2002) 
has identified three distinct paradigms in the field - modern, postmodern, and post-postmodern to reflect the stances towards branding in dialogue with the challenges and contradictions raised by consumer culture. Next, these paradigms are discussed in connection with the identified drivers of CBI.

Modern brand marketers consider themselves as cultural engineers who specify and orchestrate identities, ideals, and pleasures that can be accessed only through their brands (as material embodiments). However, this is likely to cause resistance, as marketing is easily seen as propaganda in the minds of consumers. Consumers do not necessarily value the brands based on this logic of engineering of brands, but are seeking more freedom to choose and do not tolerate the idea that they are supposed to live in accordance with a company-generated template (Holt, 2002). Instead, brand meanings are exposed to reconstruction when individually and culturally appropriated and contested by consumers (Thompson and Arsel, 2004). Thereby, it can be argued that the personality driver of $C B I$ challenges the modern way of thinking in brand personality management.

The second - postmodern - paradigm in brand management identified by Holt (2002) acknowledges that consumers seek ways of self-production in nonmarket spaces and through brands as resources, for example for their biking hobby. Postmodern brand managers admit that brands do not define a consumer, but a consumer uses a brand for self-creation and in the pursuit of optimal experiences. There is a clear quest for personal sovereignty and a more artistic consumption style. The perception of brand authenticity plays a key role in valuing brands, so that consumers are likely to value brands that appear to be original and non-commercialized (ibid, 2002). This kind of authenticity of a brand can serve consumers as a means for selfexpression of an inner personal truth (Beverland, 2005). The postmodern branding paradigm is 
premised upon the idea that brands will be more valuable if they are offered as cultural resources for consumers' identity projects. This notion goes in line with the lifestyle driver of $C B I$ with an emphasis on functional roles of the brands in consumers' lives.

Finally, the most recent, post-postmodern paradigm of branding identified by Holt (2002) realizes that brands are less orchestrated by brand managers than before. Instead, brand communities have taken an active role in being empowered brand evangelists and interpretive communities. Brand communities carry out important functions on behalf of the brand, such as sharing information, perpetuating the history and culture of the brand, and providing assistance (Holt, 2002). Members of brand communities feel that the brand belongs to them as much as it does to the manufacturer, and that they even have a better understanding of what the brand is about and how it should be like (Muniz and O'Guinn, 2001).

Brand communities are important as social networks that reflect how brands are embedded in the day-to-day lives of consumers and the ways in which brands connect the consumer to brands, and consumer to consumer. Thus, the existence of brand communities rejects the traditional consumer-brand dyad and replaces it with the consumer-brand-consumer triad. In essence, members of brand communities feel a strong connection to the brand, but an even stronger connection toward one another (Muniz and O'Guinn, 2001). Holt (2002) places brands in the role of citizen-artists in the post-postmodern era. In other words, brands are seen as cultural actors along with film stars and rock bands. In a similar vein, Beverland (2005: 461) asserts that brand managers should "let their brands be adopted by communities", and become genuine expressions of identity through community membership. Despite of having commercial motivations brands can be good and useful corporate citizens that share values with consumers. 
Thereby, the values driver of CBI is strongly linked to post-postmodern way of thinking in branding with a strong emphasis on brand community management.

\section{Implications for brand identity management}

Based on discussion above, we may identify that certain arenas of brand management are closely connected with the drivers of CBI. Brand personality management relates to the personality driver of CBI, whereas formation of brand promise comes relevant when it comes to the lifestyle driver of CBI, and management of a brand community is linked to the values driver of CBI. Accordingly, the identification of the drivers of consumer-brand identification poses three focal questions for brand management, 1) Is there a match between consumer personality and brand personality? 2) Is there a match between consumer's life tasks and brand promise? and 3) Is there a match between consumer values and brand community? Table 1 represents the alternative types of CBI's in respect of these questions and related practical implications.

Insert Table 1 here. Alternative Consumer-Brand Identifications

If all three aspects of consumer-brand identification are met (Yes-Yes-Yes), we may realize a situation of full CBI, which is the strongest identity-based manifestation of a consumer-brand relationship, as it responds to symbolic, functional, and value-based identity needs and roles in a consumer's life. This kind of relationship is likely to be very stable and long-lasting when a brand has several congruencies with a consumer. However, a brand needs to continuously keep learning from its target customers on their thoughts, behaviours, and appreciations, and to be 
able communicate the brand image aligned with those. In contrast, if none of the three aspects is met (No-No-No), no common ground exists for consumer-brand identification. Accordingly, the consumer has no reason to form a relationship with a brand that does not meet any of his/her identity needs, but rather causes an identity conflict (Reed et al., 2012). On the brand's side, we may speak of a mismatch where the brand has to find another target with whom to build a relationship. In practice, repositioning the brand and redefining target customers is needed for CBI's to develop.

In addition to the two extremes of $\mathrm{CBI}$, we may identify partial consumer-brand identifications in terms of the three drivers. 1) Yes-Yes-No: CBI is likely to be strong, but not necessarily long-lasting because of the lack of congruent values. The brand needs to communicate its values and vision to advance the creation of social commitments with the brand. 2) Yes-No-No: CBI based only on brand personality congruence is likely to be a short-term infatuation since utilitarian and experiential aspects of the relationship are missing. Accordingly, the brand has to deepen the relationship by focusing more on product functionalities, and by expressing its core values, thereby showing daily relevance to its customers that form a brand community. .3) Yes-No-Yes: CBI remains too passive since although personality and values are congruent, the brand does not receive a relevant place in the consumer's life. Therefore, the brand needs to create ways to meet consumer needs and to develop stronger product involvement among its target customers. 4) No-Yes-Yes: CBI is a utilitarian and general-minded relationship lacking symbolic value for the customer. In order to differentiate itself, a brand has to redefine its brand personality.5) No-No-Yes: CBI remains rather distant and abstract as there is only a valuecongruence between the consumer and the brand. Therefore, redefinition of brand personality and promise are needed to become relevant for target customers both in symbolic and in practical 
terms. Finally, No-Yes-No: CBI may be a very active but short-term relationship when the brand is relevant for consumer life tasks, but weak in terms of value and personality congruence. Here, the brand needs to define and communicate its personality and values to better identify with target customers, and to clarify its positioning on the market. These partial consumer-brand identifications can be altered towards stronger relationships through enhanced communications, interactions, and holistic brand identity work.

It seems plausible to suggest that if one wishes to take advantage of the personality driver, the brand personality should possess carefully selected attributes that give a clear reason to buy the brand - as it differentiates. Several studies (e.g. Aaker et al., 2004; Sung and Kim, 2010; Maehle et al., 2011, and Eisend \& Stokburger-Sauer, 2013) have tapped into the question of what kinds of personality characteristics a brand should portray in order to be successful. However, there probably is no model-fits-all solution available, but product category specific considerations are needed.

On the other hand, there is a clear rationale for directly addressing consumers in their life contexts by attaching to the personal goals and lifestyles of the consumer through a solid and intriguing brand promise instead of solely emphasizing the brand personality. In fact, Chernev et al. (2011) suggest that the consumer's need for self-expression may not be as limitless as has been assumed in prior studies. Brands are likely to face broader cross-category competition when striving to cue consumers' personalities instead of functional aspects of the brand. Perhaps, therefore, not every brand should adopt the same strategy. If one decides to ground a brand on the lifestyle driver, a careful choice of target consumers becomes essential, because if a brand fails in knowing its customers, it cannot easily fit the product to their lifestyles. 
Thirdly, consumers who are very committed to pursuing their values in life would appreciate a brand sharing this devotion and ideology. Instead of searching for an extraordinary distinct brand identity, the focus could be on finding common and relevant ground with the customer in terms of values and appreciation, and support the consumer's identification with other brand community members. Here it becomes important to monitor the change of values of target groups over time and to steer the brand values. Overall, prior literature (e.g. Schau, Muñiz, and Arnould 2009) emphasizes that a well-knit brand community not only strengthens the CBI, but creates value for both consumers and marketers in practical terms.

Embracing all three drivers at the same time is challenging, yet a worthwhile effort to take for brand identity management. As an empirical support of the benefits, Story and Hess (2006) found in they study that customers who have multidimensional (functional and personal) relationships with a brand are likely to be more loyal towards that brand, less price sensitive, willing to spend more, have a higher brand share of total purchases in the product category, and more frequent brand visits in comparison to satisfied, but disconnected customers who are likely to engage in variety seeking. To exemplify the striving towards full CBI in the car category, one brand, Jeep, distinguishes itself by displaying all three manifestations of CBI at the same time, thereby entwining the totality of having, doing, and being, with its slogan "I Live. I Ride. I Am. Jeep" from the year 2009. In many respects, the Jeep brand has already achieved the status of being an iconic car brand with loyal customers. Over the years, Jeep has showed the determination to build a solid brand identity and committed community (McAlexander et al., 2002).

Supported by the rationale of identity verification and avoiding identity conflict, whatever the driver chosen, positioning a brand in a way that it resonates with consumers' identity 
concerns is likely to influence consumers' brand appeal and thereby also their purchase decisions. DeChernatory's (1999: 157) assertion that “strong brands require homogeneous brand identity with congruent identity components" holds, but there is more to brand identity management from the viewpoint of two-way interactions with consumers. It should be acknowledged that consumer-brand relationships involve three parties: the consumer, the brand, and the brand community, each having characters influencing how the CBI will result. Yet, no matter how decisive work with the brand identity is, consumers' self-identification, and its effects on consumption, remain beyond the control of brand managers (see Lam et al., 2013; Urminsky et al., 2014).

\section{Conclusions and discussion}

This study has brought together the different threads of research on consumer identities in introducing three drivers of $\mathrm{CBI}$ in the product branding context by acknowledging different identity needs and the roles of brands in a consumer's life. On the one hand, brands have personalities, purposes, and values of their own, and on the other, consumers' personalities, lifestyles, and values can develop independently without any brand influence. Thus, the development of CBI is a two-way process. The identified three key drivers of CBI point to the need of congruence between 1) the consumer's and brand's personality, 2) the consumer's life tasks and a brand promise, and 3) the consumer's valuations in life and those of the brand community.

The identified consumer's personality driver connects with the management of brand personalities, stressing that brands can enable consumers to express themselves in their social 
encounters and enhance their self-concept. The lifestyle driver refers to the concrete and routinized behaviours in the everyday lives of consumers, which highlights that a brand can not only be symbolic, but should also be utilitarian/functional to the consumer. Finally, the values driver of CBI concerns the individual's striving for self-continuity in terms of appreciations and goals in life. Ideally, the consumer could thereby experience that the brand community shares and supports his/her aspirations and ideological concerns.

The situations of full, non-existing, and partial CBI's were distinguished and their implications to brand management were discussed. The findings of this study imply that there is no single way to success in brand identity management, but several aspects of consumer-brand relationships and related measurements, such as image congruence, product involvement, and brand commitment are of relevance.

A limitation of this conceptual study is that the study does not include primary empirical data to support the line of arguments, but instead discusses the findings of prior studies in support of conceptual assertions. Moreover, the focus was on product branding instead of corporate, human, or place branding. However, the conclusions of this study are not limited to specific product categories, but as Park et al. (1986) note, basically every product can be positioned with a symbolic image, which in turn implies the possibility of identity-connection.

There remains a need for empirical studies that would examine the relative significance of the identified key drivers of CBI in different product categories and consumer segments in varied cultural settings. Case studies that explore how companies manages their brand identities in practice, and experiences from the industry would give this kind of information are needed to advance our understanding. Furthermore, empirical examinations and theoretical modelling that would harness the ensemble of three drivers in relation to the various emotional, evaluative, 
behavioural, and social facets in brand relationships are highly encouraged as there is some trimming of thicket to do when it comes to empirical and conceptual discussions around consumer-brand relationships. Finally, there is a need to compare theory and practice to show how brand managers realise and utilise CBI's for managing brand identities.

The corresponding author states that there is no conflict of interest.

\section{References}

Aaker, J. (1997) Dimensions of brand personality. Journal of Marketing Research 34 (3): 347356.

Aaker, J., Fournier, S. and Brasel, S. A. (2004). When good brands do bad. Journal of Consumer Research 31 (June): 1-16.

Ahuvia, A. C. (2005) Beyond the extended self: loved objects and consumers' identity narratives. Journal of Consumer Research 32 (1): 171-184.

Albert, N., Merunka, D. and Valette-Florence, P. (2013) Brand passion: antecedents and consequences. Journal of Business Research 66 (7): 904-909.

Algesheimer, R., Dholakia, U.M. and Herrmann, A. (2005) The social influence of brand community: evidence from European car clubs. Journal of Marketing 69 (3): 19-34.

Ashforth, B.E., Harrison, S.H. and Corely, K.G. (2008) Identification in organizations: an examination of four fundamental questions. Journal of Management 34 (3): 325-374.

Ball, A. D. and Tasaki, L., H. (1992) The role and measurement of attachment in consumer behavior. Journal of Consumer Psychology 1 (2): 155-172. 
Bandura, A. (2001) Social cognitive theory of mass communication. Media Psychology 3 (3): $265-299$.

Batra, R., Ahuvia, A., and Bagozzi, R. P. (2012) Brand love. Journal of Marketing (76) 2: 1-16.

Baumgartner, H. (2002) Toward a personology of the consumer. Journal of Consumer Research 29 (2): 286-29.

Bell, D. and Hollows, J. (2005) Making sense of ordinary lifestyles. In: D. Bell \& J. Hollows. (eds.) Ordinary Lifestyles. Maidenhead, Berkshire: Open University press, pp. 21-34.

Berthon, P., Holbrook, M.B., Hulbert, J. M. and Pitt, L. (2007) Viewing brands in multiple dimensions. MIT Sloan Management Review 48 (2): 37-43.

Beverland, M. (2005) Brand management and the challenge of authenticity. Journal of Product and Brand Management 14 (7): 460-461.

Bhattacharya, C. B. \& Sen, S. (2003) Consumer-company identification: a framework for understanding consumers' relationships with companies. Journal of Marketing 67 (2): 76 88.

Bowden, J. (2009) Customer engagement: a framework for assessing customer-brand relationships: the case of the restaurant industry. Journal of Hospitality Marketing \& Management 18 (6): 574-596

Carroll, B.A. and Ahuvia, A.C. (2006) Some antecedents and outcomes of brand love. Marketing Letters 17 (2): 79-89.

Chernev, A., Hamilton, R. and Gal, D. (2011) Competing for consumer identity: limits to selfexpression and the perils of lifestyle branding. Journal of Marketing. 75 (3): 66-82.

Deaux K. (1992) Personalizing identity and socializing self. In: G. M. Breakwell (ed.) Social Psychology of Identity and the Self Concept. London: Surrey University Press, pp. 9-33. 
DeChernatory, L. (1999) Brand management through narrowing the gap between brand identity and brand reputation. Journal of Marketing Management 15 (1-3): 157-179.

Donavan, D.T., Janda, S. and Suh, J. (2006) Environmental influences in corporate brand identification and outcomes. Journal of Brand Management 14 (1/2): 125-136.

Eisend, M. and Stokburger-Sauer, N. (2013) Brand personality: a meta-analytic review of antecedents and consequences. Marketing Letters 24 (3): 205-216.

Escalas, J.E. (2004) Narrative processing: building consumer connections to brands. Journal of Consumer Psychology 4 (1\&2): 168-180.

Fournier, S. (1991) A meaning-based framework for the study of consumer-object relations. Advances in Consumer Research 18 (1): 736-742.

Fournier, S. (1998) Consumers and their brands: Developing relationship theory in consumer research. Journal of Consumer Research 24 (4): 343-373.

Fromm, E. (1976) To Have or to Be. (Republished in 1997). Continuum, New York.

Gambetti, R. C., Graffigna, G. and Biraghi, S. (2012), “The grounded theory approach to consumer-brand engagement”, International Journal of Market Research, 54 (5): 659-687.

Gentry J., Baker, S. M. and Kraft, F .B. (1995) The role of possessions in creating, maintaining, and preserving one's identity: variation over the life course. Advances in Consumer Research 22 (1): 413-418.

Giddens, A. (1991) Modernity and Self-Identity: Self and Society in the Late Modern Age. Stanford, CA: Stanford University Press.

Gómez-Suárez, M., Martínez-Ruiz, M. P. and Martínez-Caraballo, N. (2017) Consumer-brand relationships under the marketing 3.0 paradigm: a literature review. Frontiers in Psychology 8: 1-4. 
Halkoaho, J. (2012) Identity-Related Media Consumption: A Focus on Consumers' Relationships with their Favourite TV Programs. PhD Thesis. Vaasa: University of Vaasa Press.

Hollebeek, L. (2011). Exploring customer brand engagement: definition and themes. Journal of Strategic Marketing 19 (7): 555-573.

Holt, D. (2002) Why do brands cause trouble? A dialectical theory of consumer culture and branding. Journal of Consumer Research 29 (1): 70-90.

Huffman, C., Ratneshwar, S. and Mick, D. G. (2000) Consumer goal structures and goaldetermination processes: an integrative framework. In: S. Ratneshwar, D. G. Mick and C. Huffman (eds.) The Why of Consumption. Contemporary Perspectives on Consumer Motives, Goals, and Desires. London, UK: Routledge, pp. 9-35.

Kirmani, A. (2009) The self and the brand. Journal of Consumer Psychology 9 (3): 271-275.

Kleine, S. Schultz, Kleine III, R. E. and Allen, C. T. (1995) How is a possession "me" or "not me"? Characterizing types and antecedent of material possession attachment. Journal of Consumer Research 22 (3): 327-343.

Kressmann, F., Sirgy, M. J., Herrmann, A., Huber, F. and Lee D.-J. (2006) Direct and indirect effects of self-image congruence on brand loyalty. Journal of Business Research. 59 (9): $955-964$.

Kuenzel, S. and Halliday, S.V. (2008) Investigating antecedents and consequences of brand identification. Journal of Product \& Brand Management 17 (5): 293-304.

Lam, S.K., Ahearne, M., Mullins, R., Hayati, B. and Schillewaert, N. (2013) Exploring the dynamics of antecedents to consumer-brand identification with a new brand. Journal of the Academy of Marketing Science 41 (2): 234-252. 
Lam, S.K., Ahearne, M., and Schillewaert, N. (2012) A multinational examination of the symbolic-instrumental framework of consumer-brand identification. Journal of International Business Studies 43 (3): 306-331.

Lencastre, P. de and Côrte-Real, A. (2010). A Brand Triangle Model to Avoid Branding Myopia. The IUP Journal of Brand Management 7 (1\&2): 76-91.

MacInnis, D.J. (2011) A Framework for Conceptual Contributions in Marketing. Journal of Marketing 75 (July): 136-154.

Maehle, N., Otnes, C. and Supphellen, M. (2011) Consumers' perceptions of the dimensions of brand personality. Journal of Consumer Behavior 10 (5): 290-303.

Mael, F. and Ashforth, B. E. (1992) Alumni and their alma mater: a partial test of the reformulated model of organizational identification. Journal of Organizational Behavior 13 (2): $103-123$.

Malär, L., Krohmer, H., Hoyer, W. D. and Nyffenegger, B. (2011) Emotional brand attachment and brand personality: the relative importance of the actual and the ideal self. Journal of Marketing 75 (4): 35-52.

Mathews, J. (2015). Brand personality: Finding Compatibility between human personality and brand characteristics. The IUP Journal of Brand Management 12 (2): 21-38.

Matusitz, J. (2014). Symbolism in Terrorism: Motivation, Communication, and Behavior. Rowman \& Littlefield, Lanham, MD.

McAdams, D. P. (1996) Personality, modernity, and the storied self: a contemporary framework for studying persons. Psychological Inquiry 7 (4): 295-321.

McAlexander, J. H., Schouten, J. W. and Koenig, H. F. (2002) Building brand community. Journal of Marketing 66 (1): 38-54. 
Miles, S. (2000) Youth Lifestyles in a Changing World. Buckingham: Open University Press.

Millán, Á. and Díaz, E. (2014) Analysis of consumers' response to brand community integration and brand identification. Journal of Brand Management 21 (3): 254-272.

Muniz, A.M. and O'Guinn, T.C. (2001) Brand community. Journal of Consumer Research 27 (4): 412-432.

Nandan, S. (2005) An exploration of the brand identity - brand image linkage: a communications perspective. Journal of Brand Management 12 (4): 264-279.

O'Cass, A. (2004) Fashion clothing consumption: antecedents and consequences of fashion clothing involvement. European Journal of Marketing 38 (7): 869-882.

O'Cass, A. (2000) An assessment of consumers' product, purchase decision, advertising and consumption involvement in fashion clothing. Journal of Economic Psychology 21: 545576.

Ogilvie, D. M. and Rose, K. M. (1995) Self-with-other representations and a taxonomy of motives: two approaches to studying persons. Journal of Personality 63 (3): 643-679.

Oyserman, D. (2009) Identity-based motivation: implications for action-readiness, proceduralreadiness, and consumer behavior. Journal of Consumer Psychology 19 (3): 250-260.

Papista, E. and Dimitriadis, S. (2012) Exploring consumer-brand relationship quality and identification: qualitative evidence from cosmetics brands. Qualitative Market Research: An International Journal 15 (1): 33-56.

Park, C. W., Jaworski, B. J. and MacInnis, D. J. (1986) Strategic brand concept-image management. Journal of Marketing 50 (4): 134-145.

Quester, P. and Lim, A.L. (2003) Product involvement/brand loyalty: is there a link? Journal of Product and Brand Management 12 (1): 22-38. 
Reed, A. II (2002), "Social identity as a useful perspective for self-concept-based consumer research”, Psychology \& Marketing, 19 (3): 235-266.

Reed, A. II, Forehand, M.R., Puntoni, S. and Warlop, L. (2012) Identity-based consumer behavior. International Journal of Research in Marketing 29 (4): 310-321.

Sartre, J.-P. (1966) Being and Nothingness: An Essay on Phenomenological Ontology. Pocket Books, New York.

Schau, H. J., Muñiz, A. M. and Arnould, E. J. (2009) How brand community practices create value. Journal of Marketing, 73 (5): 30-51.

Schmitt, B. (2012) The consumer psychology of brands. Journal of Consumer Psychology 22: 7 17.

Schultz, S. E., Kleine III R. E. and Kernan, J. B. (1989) 'These are a few of my favorite things' Toward an explication of attachment as a consumer behavior construct. Advances in Consumer Research 16 (1): 359-366.

Shankar, A. and Fitchett, J.A. (2002) Having, Being and Consumption. Journal of Marketing Management 18 (5/6): 501-516.

Sirgy, M. J. (1982) Self-concept in consumer behavior: a critical review. Journal of Consumer Research 9 (3): 287-300.

Sivadas, E. and Venkatesh, R. (1995) An examination of individual and object-specific influences on the extended self and its relation to attachment and satisfaction", Advances in Consumer Research 22 (1): 406-412.

Smit, E., Bronner, F. and Tolboom, M. (2007) Brand relationship quality and its value for personal contact. Journal of Business Research 60 (6): 627-633. 
Sprott, D., Czellar, S. and Spangenberg, E. (2009) The importance of a general measure of brand engagement on market behavior: development and validation of a scale. Journal of Marketing Research 46 (1): 92-104.

Stokburger-Sauer, N., Ratneshwar. S. and Sen, S. (2012) Drivers of consumer-brand identification. International Journal of Research in Marketing 29 (4): 406-418.

Sung Y. and Kim, J. (2010) Effects of brand personality on brand affect and brand trust. Psychology \& Marketing 27 (7): 639-661.

Swaminathan, V., Page, K.L. and Gürhan-Canli, Z. (2007) My' brand or 'our' brand: the effects of brand relationship dimensions and self-construal on brand evaluations. Journal of Consumer Research 34 (2): 248-259.

Swaminathan, V., Stilley, K. M. and Ahluwalia, R. (2009) When brand personality matters: the moderating role of attachment styles. Journal of Consumer Research 35 (6): 985-1002.

Story, J. and Hess, J. (2006).Segmenting customer-brand relations: beyond the personal relationship metaphor. Journal of Consumer Marketing 23 (7): 406-413.

Thompson, C. J. and Arsel, Z. (2004) The Starbucks brandscape and consumers' (anticorporate) experiences of glocalization. Journal of Consumer Research 31 (3): 631-642.

Thompson, C. J., Rindfleisch, A. and Arsel, Z. (2006) Emotional branding and the strategic value of the doppelgänger brand image. Journal of Marketing 70 (1): 50-64.

Thomson, M., MacInnis, D. J., and Park, C. W. (2005) The ties that bind: measuring the strength of consumers' emotional attachments to brands. Journal of Consumer Psychology 15 (1): $77-91$.

Tuškej, U., Golob, U. and Podnar, K. (2013) The role of consumer-brand identification in building brand relationships. Journal of Business Research 66 (1): 53-59. 
Urminsky, O., Bartels, D. M., Giuliano, P., Newman, G. E., Puntoni, S. and Rips, L. (2014) Choice and self: how synchronic and diachronic identity shape choices and decision making. Marketing Letters 25 (3): 281-291.

Wallendorf, M. and Arnould, E. (1988) 'My favorite things': A cross-cultural inquiry into object attachment, possessiveness, and social linkage. Journal of Consumer Research 14 (4): 531547.

Wattanasuwan, K. (2005) The self and symbolic consumption. The Journal of American Academy of Business, Cambridge 6 (1): 179-184.

Zaichkowsky, J. L. (2010) Strategies for distinctive brands. Journal of Brand Management. 17 (8): 548-560. 
Figure 1. The three drivers of consumer-brand identification

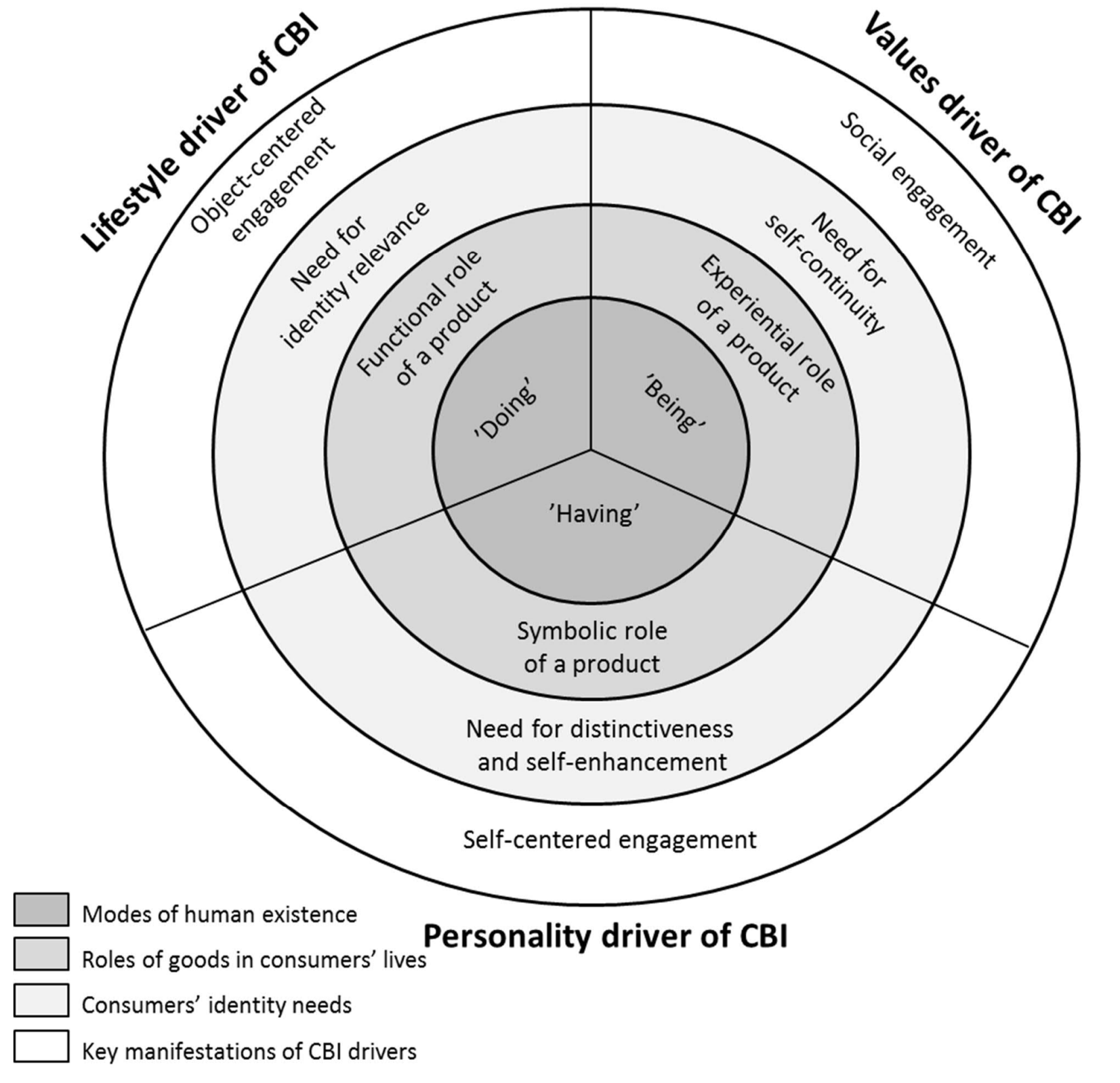


Table 1. Alternatives for Consumer-Brand Identifications

\begin{tabular}{|c|c|c|}
\hline $\begin{array}{l}\text { CBI- } \\
\text { alternatives }\end{array}$ & Type of CBI & $\begin{array}{l}\text { Practical implications for } \\
\text { brand management }\end{array}$ \\
\hline $\begin{array}{l}\text { Full CBI } \\
\text { "Yes-Yes-Yes" }\end{array}$ & $\begin{array}{l}\text { There is a match between 1) consumer } \\
\text { personality and brand personality, 2) } \\
\text { consumer's life tasks and brand promise, } \\
\text { and 3) consumer values and brand } \\
\text { community. }\end{array}$ & $\begin{array}{l}\text { Keep learning from your } \\
\text { target customers on their } \\
\text { thoughts, behaviours, and } \\
\text { appreciations, and } \\
\text { communicate the brand } \\
\text { image aligned with those. }\end{array}$ \\
\hline $\begin{array}{l}\text { Non-existing } \\
\text { CBI } \\
\text { "No-No-No" }\end{array}$ & $\begin{array}{l}\text { There is no match between 1) consumer } \\
\text { personality and brand personality, 2) } \\
\text { consumer's life tasks and brand promise, } \\
\text { or 3) consumer values and brand } \\
\text { community. }\end{array}$ & $\begin{array}{l}\text { Reposition the brand and } \\
\text { redefine your target } \\
\text { customers to find a } \\
\text { common ground for CBI's } \\
\text { to develop. }\end{array}$ \\
\hline $\begin{array}{l}\text { Partial CBI } \\
\text { "Yes-Yes-No" }\end{array}$ & $\begin{array}{l}\text { There is a match between 1) consumer } \\
\text { personality and brand personality, and 2) } \\
\text { consumer's life tasks and brand promise, } \\
\text { but not between } 3 \text { ) consumer values and } \\
\text { brand community. }\end{array}$ & $\begin{array}{l}\text { Communicate your brand } \\
\text { values and vision to } \\
\text { advance the creation of } \\
\text { social commitments with } \\
\text { the brand. }\end{array}$ \\
\hline $\begin{array}{l}\text { Partial CBI } \\
\text { "Yes-No-No" }\end{array}$ & $\begin{array}{l}\text { There is a match between 1) consumer } \\
\text { personality and brand personality, but not } \\
\text { between 2) consumer's life tasks and } \\
\text { brand promise, or } 3 \text { ) consumer values and } \\
\text { brand community. }\end{array}$ & $\begin{array}{l}\text { Focus more on functionality } \\
\text { and core values. Show daily } \\
\text { relevance to the customers } \\
\text { that form a brand } \\
\text { community. }\end{array}$ \\
\hline $\begin{array}{l}\text { Partial CBI } \\
\text { "Yes-No-Yes" }\end{array}$ & $\begin{array}{l}\text { There is a match between 1) consumer } \\
\text { personality and brand personality, and } 3 \text { ) } \\
\text { consumer values and brand community, } \\
\text { but not between 2) consumer's life tasks } \\
\text { and brand promise. }\end{array}$ & $\begin{array}{l}\text { Create ways to meet } \\
\text { consumer needs and to } \\
\text { develop stronger product } \\
\text { involvement among your } \\
\text { target customers. }\end{array}$ \\
\hline $\begin{array}{l}\text { Partial CBI } \\
\text { "No-Yes-Yes" }\end{array}$ & $\begin{array}{l}\text { There is a match between 2) consumer's } \\
\text { life tasks and brand promise, and 3) } \\
\text { consumer values and brand community, } \\
\text { but not between 1) consumer personality } \\
\text { and brand personality. }\end{array}$ & $\begin{array}{l}\text { Redefine your brand } \\
\text { personality to find image } \\
\text { congruence with the target } \\
\text { customers and to stand out } \\
\text { in the markets. }\end{array}$ \\
\hline $\begin{array}{l}\text { Partial CBI } \\
\text { "No-No-Yes" }\end{array}$ & $\begin{array}{l}\text { There is a match between 3) consumer } \\
\text { values and brand community, but not } \\
\text { between 1) consumer personality and } \\
\text { brand personality, 2) consumer's life } \\
\text { tasks and brand promise. }\end{array}$ & $\begin{array}{l}\text { Redefine your brand } \\
\text { personality and promise to } \\
\text { become relevant for target } \\
\text { customers both in symbolic } \\
\text { and in practical terms. }\end{array}$ \\
\hline $\begin{array}{l}\text { Partial CBI } \\
\text { "No-Yes-No" }\end{array}$ & $\begin{array}{l}\text { There is a match between 2) consumer's } \\
\text { life tasks and brand promise, but not } \\
\text { between 1) consumer personality and } \\
\text { brand personality, or 3) consumer values } \\
\text { and brand community. }\end{array}$ & $\begin{array}{l}\text { Define and communicate } \\
\text { the brand personality and } \\
\text { values to better identify } \\
\text { with target customers, and } \\
\text { to clarify brand positioning. }\end{array}$ \\
\hline
\end{tabular}

